\title{
SPRING BOOKS
}

\section{Evolution of the selfish gene}

The thirtieth anniversary of Richard Dawkins' landmark work provides an opportunity to take stock.

\author{
Richard Dawkins: How a Scientist Changed \\ the Way We Think \\ edited by Alan Grafen \& Mark Ridley \\ Oxford University Press: 2006. 304 pp. \\ $\notin 12.99, \$ 25$
}

\section{Dan Sperber}

"We are survival machines - robot vehicles blindly programmed to preserve the selfish molecules known as genes. This is a truth which still fills me with astonishment ... One of my hopes is that I may have some success in astonishing others." That hope, expressed by Richard Dawkins in the preface of The Selfish Gene, has been more than fulfilled. Published 30 years ago, The Selfish Gene has been, and remains, one of the most influential science books of all time. To celebrate this anniversary, a third edition has been released, along with Richard Dawkins: How a Scientist Changed the Way We Think. The latter is a collection of comments and testimonials edited by Alan Grafen and Mark Ridley.

In the 1960s and '70s, biologists such as William Hamilton, John Maynard Smith, Robert Trivers and G. C. Williams sought to explain troubling aspects of evolution by approaching them at the level of genes, rather than at the usual level of individual organisms, groups or species. The existence of altruistic behaviour that may decrease the reproductive success of altruistic individuals, for instance, presents a puzzle for standard darwinism. Hamilton showed that altruistic behaviour may increase the chances of the genes involved being replicated when the beneficiaries are also carriers of the same genes; this gene-level selection explains the evolution of altruism.

What Dawkins did was integrate such findings into a vivid and systematic picture of biological evolution wholly "from the point of view of the gene" and explore the wider implications of this approach. His picture challenges common-sense ontology and expectations, and is indeed astonishing. We spontaneously interpret the behaviour of individuals as that of agents capable of pursuing their interest, and extend this kind of interpretation to social groups. Fragments of molecules, on the other hand, are unfamiliar objects to which we are not disposed to attribute interests and goals. Of course, genes are not literally agents, let alone selfish ones intent on propagating themselves, but analysing what they would do if

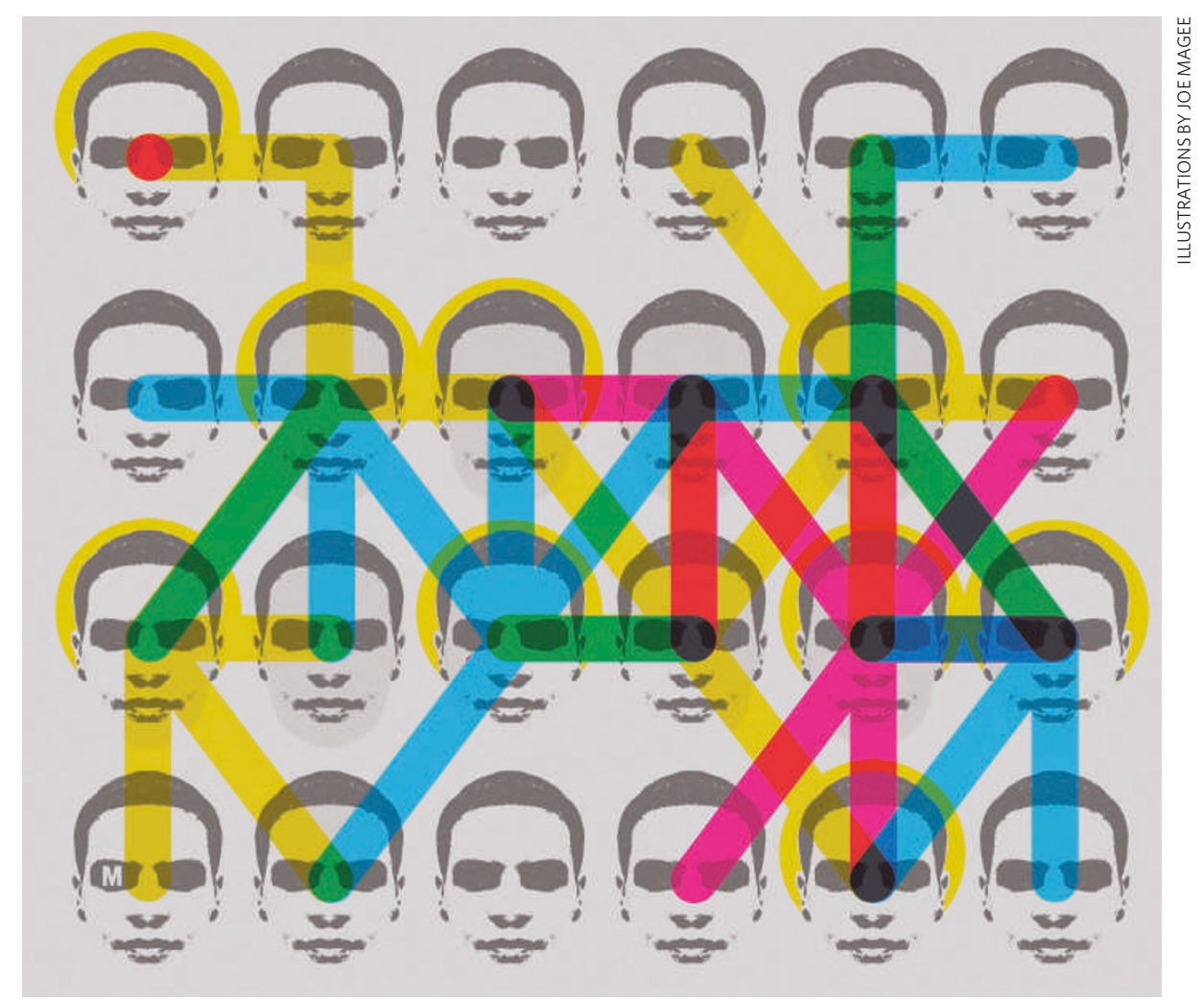

they were provides us with a uniquely cogent account of their actual effects on the world. The logic is that used by Darwin when he explained the existence in nature of design without a designer as an effect of selection. Dawkins shows how this logic can be exploited at the micro-level of 'replicators', or genes.

Whether evolution and selection are best described at the level of genes, or at the higher levels of organisms or groups, or at all these levels simultaneously, remains contentious (with echoes of the debate in Grafen and Ridley's edited volume, Richard Dawkins). There is little doubt, however, that the gene-centred approach has been the source of novel and deep insights. In particular, further challenging common sense, Dawkins attacked the view of organisms as bearers of life par excellence. Only in some cases do different replicators cooperate in such a way that larger coherent units - the 'vehicles' of replicators - emerge. Not all these vehicles correspond to the individual organism. In The Extended Phenotype, his second book and possibly his best, Dawkins showed how the vehicles may extend beyond the boundaries and behaviour of organisms, for example when the genes of parasites express themselves by modifying their host's

In the last chapter of the first edition of The Selfish Gene, Dawkins introduced what may be his most popular idea, that of 'memes', or cultural replicators. Any population of entities that produce copies of themselves, and that vary both in their specific features and in their reproductive success, are replicators and are thus candidates for darwinian selection. The idea that cultural evolution might be modelled along darwinian lines had often been suggested, but Dawkins reformulated it with characteristic crispness and clarity. Contrary to the idea that cultural items (such as ideas, skills, practices and artefacts) thrive because of their contribution to the social or biological welfare of the individual or groups that adopt them, Dawkins argued that cultural items may thrive because they cause their own propagation. Establishing the possibility of such 'selfish memes' served two purposes: generalizing the idea of replicators behaviour. 
beyond biology, and suggesting an evolutionary approach to culture.

However, as Robert Aunger observes in Grafen and Ridley's book: "No significant body of empirical research has grown up around the meme concept ... In fact the memetic literature remains devoted almost exclusively to theoretical antagonisms, internecine battles, and scholastic elucidations of prior writing on memes." Dawkins has essentially left the development of memetics to others. Instead, together with Daniel Dennett, he has used the idea of the meme as a powerful tool in his criticism of religious ideas, which he describes as "viruses of the mind". The effectiveness of the criticism does not much depend on the scientific details of a would-be memetics.

Dawkins' depth and clarity of vision, intellectual honesty and passion, and superb writing have indeed changed the way many of us think about biology. And the latest volume, Richard Dawkins, brings together testimonials and reflections about Dawkins himself or inspired by his work. Most of the contributions, by eminent scientists, philosophers and writers, are laudatory; a few are critical. The book is a pleasant read and throws useful light on the multiform impact of Dawkins' work on biology, philosophy, science writing and the public debate on science and religion. Particularly illuminating are Grafen's chapter discussing the relationship between Dawkins' work and more mathematically oriented population genetics, and Ullica Segerstråle's chapter on Dawkins and sociobiology. Still, in preparing this review, I re-read The Selfish Gene, and this was the real treat.

Dan Sperber is at the Centre National de la

Recherche Scientifique and the Institut Jean Nicod, 1 bis avenue Lowendal, 75014 Paris, France.

\section{Renaissance magic and mysticism}

\section{The Devil's Doctor: Paracelsus and the World of Renaissance Magic and Science by Philip Ball \\ Heinemann/Farrar, Straus, Giroux: 2006. 448 pp. $£ 20 / \$ 26$}

\section{Rina Knoeff}

One has to admire Philip Ball's courageous undertaking in writing a biography of Paracelsus, arguably the most controversial medical writer in the Renaissance. Not only are the works of Paracelsus' own hand extremely difficult to read and understand but, more importantly, historical reconstructions of his life and thoughts complicate the picture to such an extent that it is hard to write a 'fair' biography.

Paracelsus is known for being a failed physician; a psychiatric subject in the casebooks of the psychoanalyst Carl Jung; a German national hero during the Nazi period; and the founder of biochemistry. Ball, however, sets Paracelsus in the social, religious and cultural life of his time, a refreshing move away from the tendency to describe early 'scientists' as the forerunners of today's scientific developments

Ball is aware of the historiographic difficulties surrounding the life and work of Paracelsus. His account starts with a brief discussion of how magic and occult forces were accepted parts of early modern science. In addition, Ball acknowledges the close connection between early modern natural philosophy, Renaissance humanism and Reformation religion. In so doing, he follows a fairly recent trend in the history of science and medicine in which religion and science are seen as mutually shaping fields of knowledge.

In The Devil's Doctor, Ball convincingly shows that in order to understand Paracelsus' work and personality we must accept that "in the philosophy of Paracelsus science and rationalism do not compete with mysticism and superstition but blend with it, producing a world that now seems at the B same time wonderful and bizarre". Paracelsus, or Philippus Aureolus Theophrastus Bombastus von Hohenheim, spoke to the imagination. He is said to have ridden a magical white horse, to have cured many incurable diseases, and to have carried an enormous sword with magical powers, as well as the secret elixir of life. His name was linked with those of Faust and Martin Luther, and among the many miracles he allegedly performed was the creation of a living, human-like being.

Today, Paracelsus appears as a hero in the magical world of J. K. Rowling's Harry Potter novels. Yet, perhaps because of the intricate mixture of paracelsian magic, metallurgy, medicine and alchemy, the historical Paracelsus has received comparatively little attention. By presenting the work of Paracelsus, including all the contradictions and neologisms, as an intensely personal enterprise embedded in Renaissance life, Ball circumvents many of the historical difficulties and comes up with an excellent biography that is relevant for historians and general readers alike.

Ball takes events in the life of Paracelsus as starting points for discussing the Renaissance world. For instance, when discussing Paracelsus' life as a vagabond, Ball speaks about the difficulties of travelling in early modern Europe. His discussion of the alchemy of Paracelsus transforms into a discussion of economic growth and the power of miners, and his religious and political views are compared to those of reformers and princes. Ball speaks of Paracelsus' views on astrology in relation to the astronomy of Copernicus and his followers. And last but not least, Ball writes extensively about the traditional (galenic) medicine and chemistry that Paracelsus challenged. The book's illustrations provide a vivid picture of the time and further enliven Ball's account.

This approach is brave and enriching but is also a little overwhelming. At times Paracelsus disappears into the background, and the reader is in danger of getting lost in detailed descriptions of Renaissance culture. Moreover, in a book as ambitious as this it is almost unavoidable that the terminology becomes at times confusing. Much of Paracelsus' work teeters on the brink of the spiritual, and his own vocabulary often seems puzzling to modern readers.

The difficulty in understanding Paracelsus' neologisms and expressions is clearly visible in this book. Ball, for instance, is often wobbly in calling details of Paracelsus' work 'mechanical', 'spiritual' or 'materialistic'. Sometimes it is not clear whether he adopts Paracelsus' own words or gives them a modern, and therefore different, meaning. For example, Ball maintains that Paracelsus' concentration of nature's potencies in the preparation of medicines was "not mechanical” (presumably in a modern sense), but on the next page he states that, according to Paracelsus, the powers of the stars permeate "mechanically" through the Universe (thereby referring to Paracelsus' own words). In both cases Ball refers to the working of invisible powers, but apparently these are mechanical in one case but not in the other, leaving it unclear what Paracelsus meant when he spoke of the mechanical working of the invisible forces of nature. The same goes for the important paracelsian distinction between the material and the spiritual, which at times makes Ball's description of Paracelsus' thoughts somewhat bewildering.

To be fair to Ball, he does explain many of Paracelsus' neologisms, but he also has the 